\title{
Motilitas dan Recovery Rate Spermatozoa Ayam Kampung dengan berbagai Waktu Pre-freezing
}

\author{
Nurwahidah $^{1^{*}}$, Muhammad Erik Kurniawan ${ }^{1}$ \\ ${ }^{1}$ Program Studi Peternakan, Fakultas Sains dan Teknologi, Universitas Muhammadiyah Sinjai. \\ Jl. Teuku Umar No. 8, Biringere, Sinjai Utara 92611, Sulawesi Selatan, Indonesia \\ *nurwahidah1099@gmail.com
}

\section{INFORMASI ARTIKEL}

Diterima 23 Juni 2021

Hasil revisi diterima 24

Juni 2021

Diterbitkan 24 Juni

2021

Publish online 24 Juni 2021

Kata-kata kunci: Ayam Kampung; Spermatozoa; Waktu pre-freezing; Motilitas;

Recovery rate;

\section{ARTICLE INFO}

Article history

Received 23 June 2021

Received in revised

from 23 June 2021

Accepted 24 June 2021

Available online. 24

June 2021

Key Words:

Kampung chicken;

Spermatozoa;

Pre-freezing time;

Motility;

Recovery rate;
ABSTRAK

Penelitian ini bertujuan untuk mengetahui pengaruh waktu prefreezing terhadap motilitas dan recovery rate $(R R)$ spermatozoa ayam kampung. Rancangan percobaan yang digunakan dalam penelitian ini adalah Rancangan Acak Lengkap (RAL) dengan 5 taraf perlakuan yaitu tanpa pre-freezing, lama pre-freezing 5 menit, lama pre-freezing 10 menit, lama pre-freezing 15 menit, lama pre-freezing 20 menit. Semen yang telah dikoleksi dari ayam kampung selanjutnya diencerkan dan dikemas ke dalam straw. Straw diekuilibrasi selama 2 jam kemudian ditempatkan di atas permukaan nitrogen cair dengan jarak $4 \mathrm{~cm}$ (pre-freezing) dengan waktu sesuai perlakuan. Setelah prefreezing dimasukkan ke dalam container selama 24 jam kemudian thawing pada suhu $37^{\circ} \mathrm{C}$ untuk diperiksa motilitas dan recovery rate (RR) spermatozoanya. Hasil penelitian ini menunjukkan bahwa waktu pre-freezing mempunyai pengaruh yang sangat nyata terhadap motilitas dan RR spermatozoa. Berdasarkan penelitian ini, waktu yang terbaik untuk proses pre-freezing pada spermatozoa ayam kampung yaitu 20 menit. 


\section{PENDAHULUAN}

Ayam lokal di Indonesia adalah kekayaan alam yang merupakan aset nasional yang tidak ternilai harganya (Badaruddin et al., 2013). Ayam lokal disebut juga dengan istilah ayam bukan ras (buras) atau lebih dikenal di kalangan masyarakat sebagai ayam kampung. Ayam kampung merupakan ayam asli Indonesia yang telah beradaptasi, hidup, berkembang, dan bereproduksi dalam jangka waktu yang lama. Dilihat dari prospek pengembangan dan permintaan pasar, ayam buras merupakan salah satu hasil peternakan yang sangat diminati pada saat ini (Aedah et al, 2016). Namun dalam pengembangan ayam buras terdapat beberapa hambatan untuk pemenuhan dan pengembangan produksinya. Populasi beberapa jenis ayam buras di Indonesia terancam dengan populernya ayam ras yang menjadi bahan konsumsi protein hewani utama untuk masyarakat Indonesia.

Salah satu upaya pelestarian plasma nutfah ayam buras adalah dengan kriopreservasi semen atau lebih dikenal dengan pembekuan semen. Pembekuan semen bertujuan untuk memperpanjang daya hidup spermatozoa. Hal ini sesuai dengan pendapat Feradis (2010), yang menyatakan bahwa spermatozoa yang dibekukan dan disimpan pada suhu $-196{ }^{\circ} \mathrm{C}$ di dalam nitrogen cair dapat bertahan hidup untuk waktu yang tak terhingga. Sedangkan menurut Fulton (2006), teknik kriopreservasi menjadi alat yang sangat berharga bagi industri unggas.

Pembekuan semen merupakan proses pengeringan fisik yang meliputi dua tahap, yaitu pre-freezing dan freezing. Proses prefreezing yaitu straw yang berisi semen disusun pada rak straw dan ditempatkan dalam uap nitrogen cair. Sedangkan menurut Partodihardjo (1992), proses pre-freezing adalah proses setelah semen diisikan ke dalam straw yang dilakukan dengan cara diletakkan di canister dan digantungkan dalam uap nitrogen cair selama beberapa menit.

Lama waktu pre-freezing menurut beberapa sumber adalah beragam. Berdasarkan peraturan Direktur Jenderal Peternakan Nomor: 12207/Hk.060/F/12/2007, proses pembekuan pada tahap pre-freezing dilakukan selama 5-9 menit diatas nitrogen cair. Amin et al., (1998) dalam penelitiannya menerapkan lama waktu pre-freezing adalah 10 menit di atas permukaan nitrogen cair (suhu sekitar $-130^{\circ} \mathrm{C}$ ).

Berdasarkan uraian di atas diketahui bahwa penentuan standar waktu pre-freezing selama ini hanya berlaku pada ternak sapi, sedangkan pada ayam buras belum diketahui secara pasti waktu pre-freezing yang tepat untuk diterapkan, oleh karena itu pada penelitian ini diadakan penelitian uji kualitas spermatozoa pada ayam kampung dengan waktu prefreezing yang berbeda. Tujuan dari penelitian ini adalah untuk mengetahui pengaruh waktu pre-freezing terhadap motilitas dan RR spermatozoa ayam kampung.

\section{METODE PENELITIAN}

\section{Rancangan Penelitian}

Rancangan percobaan yang digunakan dalam penelitian ini adalah Rancangan Acak Lengkap (RAL) dengan 5 perlakuan dan 3 ulangan. Adapun perlakuan sebagai berikut :

$$
\begin{array}{ll}
\mathrm{P} 0 & =\text { tanpa pre-freezing } \\
\mathrm{P} 1 & =\text { lama pre-freezing } 5 \text { menit } \\
\mathrm{P} 2 & =\text { lama pre-freezing } 10 \text { menit } \\
\mathrm{P} 3 & =\text { lama pre-freezing } 15 \mathrm{menit} \\
\mathrm{P} 4 & =\text { lama pre-freezing } 20 \text { menit }
\end{array}
$$

\section{Prosedur Penelitian}

\section{Pemeliharaan Ayam Buras}

Tahap pemeliharaan dimulai dengan menyiapkan kandang individu berukuran $40 \mathrm{x}$ $50 \times 70 \mathrm{~cm}$ yang dilengkapi dengan tempat pakan dan tempat minum. Ayam Kampung 
jantan yang digunakan untuk diambil semennya yaitu ayam sehat dan tidak cacat, dengan panjang taji minimal $0,5 \mathrm{~cm}$ (ayam yang berumur minimal 10 bulan). Pakan yang digunakan adalah konsentrat, dedak dan jagung.

\section{Koleksi Semen}

Koleksi atau penampungan semen pada ayam dilakukan dengan menggunakan metode pengurutan (masase) pada bagian punggung ayam jantan. Penampungan semen dilakukan oleh dua orang. Seorang memegang ayam jantan yang akan ditampung semennya dan seorang lagi melakukan pengurutan untuk mengeluarkan semen dari alat kelamin ayam sekaligus menampungnya.

Pembuatan Pengencer

Bahan pengencer dasar yang digunakan adalah ringer laktat dan kuning telur. Ringer laktat kuning telur dihomogenkan menggunakan stirrer selama 5 menit kemudian disentrifugasi selama 20 menit dengan kecepatan 2.000 rpm. Bahan pengencer dasar kemudian ditambahkan dimethylsulfoxide (DMSO) 7\%, streptomisin $1 \mathrm{mg} / \mathrm{ml}$ dan penisilin $1000 \mathrm{IU} / \mathrm{ml}$.

\section{Pengenceran dan Pengemasan Semen}

Semen yang telah diencerkan kemudian dikemas ke dalam 5 mini straw (IMV, France) 0,25 $\mathrm{ml}$ dengan menggunakan spoit, kemudian ujung ministraw dipanaskan pada heating table hingga tertutup.

\section{Ekuilibrasi, Pre-freezing, dan Penyimpanan}

Tahap ekuilibrasi yaitu semen yang telah dikemas ditempatkan di dalam kulkas pada suhu $5^{\circ} \mathrm{C}$ selama 2 jam (Bearden et al., 2004). Tahap pre-freezing dilakukan dengan cara meletakkan ministraw di rak straw $4 \mathrm{~cm}$ di atas permukaan nitrogen cair. Masing-masing straw disimpan sesuai perlakuan waktu, yaitu 0 menit, 5 menit, 10 menit, 15 menit, dan 20 menit. Setelah itu, pada tahap freezing (penyimpanan) dilakukan dengan memasukkan ministraw ke dalam nitrogen cair dengan suhu $-196^{\circ} \mathrm{C}$ selama 24 jam. Thawing
Tahap thawing yaitu mencairkan semen dalam ministraw yang telah dibekukan. Proses thawing dilakukan dengan cara memasukkan ministraw ke dalam air hangat bersuhu $37^{\circ} \mathrm{C}$ selama 30 detik untuk pemeriksaan motilitas dan recovery rate spermatozoa.

\section{Parameter Yang Diamati}

\section{Motilitas spermatozoa}

Motilitas spermatozoa yaitu pergerakan individu spermatozoa yang pengukurannya dilakukan dengan meletakkan semen di atas gelas objek sebanyak satu tetes dan ditutup dengan cover glass, selanjutnya diamati pergerakannya di bawah mikroskop dengan perbesaran 16 x 40 . Spermatozoa yang motil akan terlihat bergerak maju ke depan/progresif.

\section{Recovery Rate Spermatozoa}

Recovery Rate (RR) spermatozoa adalah kemampuan pemulihan spermatozoa setelah pembekuan dengan membandingkan persentase sperma motil pada semen segar dengan pasca thawing (Garner dan Hafez, 2000) . Persentase recovery rate dapat dihitung dengan rumus sebagai berikut:

$R R=\frac{\text { motilitas spermatozoa setelah thawing }}{\text { motilitas spermatozoa segar }} \times 100 \%$

\section{Analisis Data}

Data yang diperoleh di analisis ragam berdasarkan Rancangan Acak Lengkap (RAL) dengan 5 taraf perlakuan. Model matematika yang digunakan sebagai berikut :

$$
Y i j=\mu+T i+\varepsilon i j
$$

Keterangan :

$$
\begin{aligned}
& \text { Yij = Hasil pengamatan pada waktu } \\
& \mu \quad=\text { Rata-rata pengamatan } \\
& \mathrm{Ti}=\text { Pengaruh perlakuan ke-i } \\
& \text { eij = Galat percobaan dari perlakuan ke-i }
\end{aligned}
$$




\section{HASIL DAN PEMBAHASAN}

Hasil analisis ragam menunjukkan bahwa kualitas spermatozoa dengan berbagai waktu prefreezing yang berbeda berpengaruh sangat nyata $(\mathrm{P}<0,01) \quad$ terhadap motilitas spermatozoa ayam kampung. Hal ini sejalan dengan pernyataan Purwasih et al. (2013), bahwa Proses prefreezing akan mempengaruhi gerakan individu atau daya gerak spermatozoa, persentase hidup dan abnormalitas spermatozoa.

Tabel 1. Motilitas spermatozoa ayam kampung setelah thawing dengan berbagai waktu prefreezing

\begin{tabular}{cc}
\hline Perlakuan & Motilitas Setelah Thawing $(\%)$ \\
\hline P0 & $0,00 \pm 0,00^{\mathrm{a}}$ \\
P1 & $25,00 \pm 5,00^{\mathrm{b}}$ \\
P2 & $30,00 \pm 8,67^{\mathrm{bc}}$ \\
P3 & $30,00 \pm 5,00^{\mathrm{bc}}$ \\
P4 & $36,67 \pm 5,77^{\mathrm{c}}$
\end{tabular}

Keterangan :superskrip yang berbeda pada kolom yang sama menunjukkan perbedaan yang sangat nyata $(\mathrm{P}<0,01) . \mathrm{P} 0$ : tanpa pre-freezing, $\mathrm{P} 1$ : pre-freezing 5 menit, P2 : pre-freezing 10 menit, $\mathrm{P} 3$ : pre-freezing 15 menit, $\mathrm{P} 4$ : prefreezing 20 menit.

Persentase motilitas tertinggi ditunjukkan oleh semen dengan lama prefreezing 20 menit (P4) yaitu $36,67 \%$ namun tidak berbeda nyata dengan waktu prefreezing 10 menit dan 15 menit. Nilai ini lebih tinggi dari waktu prefreezing 5 menit dan tanpa prefreezing. Hal ini menunjukkan semakin lama waktu prefreezing semakin meningkatkan motilitas spermatozoa setelah thawing, yang disebabkan oleh semakin lamanya waktu adaptasi bagi spermatozoa sebelum penyimpanan. Menurut Pratiwi et al. (2014), kurangnya waktu adaptasi spermatozoa terhadap suhu dingin sebelum dimasukkan ke dalam nitrogen cair $\left(-196^{\circ} \mathrm{C}\right)$ menyebabkan spermatozoa banyak mengalami kerusakan akibat cold shock dan perubahan-perubahan intraseluler yang berkaitan dengan pembentukan kristal-kristal es.

Salamon (1971) menyatakan bahwa ketika semen diuapkan (pre-freezing) selama beberapa menit sebelum direndam nitrogen cair, akan mempertahankan persentase gerakan individu (motilitas) spermatozoa setelah diperiksa post thawing motility. Pada penelitian ini (tabel 1) menunjukkan bahwa perlakuan tanpa prefreezing menyebabkan penurunan motilitas yang sangat tajam hingga 0\%. Hal ini serupa dengan laporan Purwasih et al. (2013) bahwa gerakan individu spermatozoa sapi jawa terendah terdapat pada perlakuan tanpa prefreezing. Lebih lanjut dinyatakan bahwa hal tersebut disebabkan spermatozoa mati karena mengalami cold shock. Spermatozoa akan rusak bila dibekukan langsung padasuhu dibawah $0^{\circ} \mathrm{C}$, karena terjadi kejutan temperatur (cold shock) yang akan mengakibatkan spermatozoa kehilangan persentase hidupnya.

Tabel 2. Recovery Rate spermatozoa ayam kampung setelah thawing dengan berbagai waktu prefreezing.

\begin{tabular}{lc}
\hline Perlakuan & Recovery rate $(\%)$ \\
\hline P0 & $0,00 \pm 0,00^{\mathrm{a}}$ \\
P1 & $30,51 \pm 5,19^{\mathrm{b}}$ \\
P2 & $36,64 \pm 10,16^{\mathrm{bc}}$ \\
P3 & $36,64 \pm 5,02^{\mathrm{bc}}$ \\
P4 & $45,10 \pm 8,49^{\mathrm{c}}$ \\
\hline
\end{tabular}

Keterangan :superskrip yang berbeda pada kolom yang sama menunjukkan perbedaan yang sangat nyata $(\mathrm{P}<0,01) . \mathrm{P} 0$ : tanpa pre-freezing, $\mathrm{P} 1$ : pre-freezing 5 menit, P2 : pre-freezing 10 menit, P3 : pre-freezing 15 menit, P4 : prefreezing 20 menit.

Motilitas spermatozoa setelah thawing dengan perlakuan waktu prefreezing 20 menit yang diperoleh pada penelitian ini lebih tinggi dari yang didapatkan pada penelitian sebelumnya pada spermatozoa ayam kampung dengan waktu pre-freezing 10 menit yaitu $36,25 \%$ (Khaeruddin dan Kurniawan, 2020), $31,50 \%$ (Khaeruddin, 2020), 32\% (Khaeruddin et al., 2020), 21,25\% 
(Khaeruddin et al., 2019). Hasil penelitian ini juga lebih tinggi dari penelitian Malik (2018) bahwa motilitas spermatozoa ayam kampung dengan waktu prefreezing 4 menit yaitu $29,27 \%$.

Recovery Rate (RR) spermatozoa adalah kemampuan pemulihan spermatozoa setelah pembekuan dengan membandingkan persentase sperma motil pada semen segar dengan pasca thawing (Garner dan Hafez, 2000). Dari hasil analisis ragam menunjukkan perlakuan waktu pre-freezing berpengaruh sangat nyata $(\mathrm{P}<0,01)$ terhadap nilai $\mathrm{RR}$. Pada waktu prefreezing 20 menit (P4) menunjukkan persentase Recovery Rate paling tinggi yakni $45,10 \pm 8,49 \%$. Nilai ini lebih tinggi dari hasil penelitian sebelumnya yaitu 25,13-36,83 \% (Khaeruddin et al, 2019) dan 27,10-35,4\% (Khaeruddin et al., 2020) menggunakan waktu pre-freezing 10 menit.

\section{KESIMPULAN}

Lama waktu pre-freezing berpengaruh terhadap motilitas dan recovery rate spermatozoa ayam kampung. Lama proses pre-freezing yang terbaik yaitu 20 menit.

\section{DAFTAR PUSTAKA}

Aedah, S., Djoefrie, M.H.B., \& Suprayitno, G. (2016). Faktor-faktor yang mempengaruhi daya saing industri unggas ayam kampung (studi kasus PT Dwi dan Rachmat Farm, Bogor). Manajemen IKM, 11(2), 173-182.

Amin, M.R., Toelihere, M. R., Yusuf, T.L., \& Situmorang, P. (1999). Pengaruh plasma semen sapi terhadap kualitas semen beku kerbau lumpur (Bubalus bubalis). Jurnal Ilmu Ternak dan Veteriner, 4(3), 143147.

Badaruddin, R.J., Hafoloan, T., \& Yuanta. (2013). Analisis fenotip genetik ayam kampung tolaki pada masa pertumbuhan. Jurnal Peternakan UGM, 37 (2), 79-86.

Bearden, H.J., Fuquay, J.W., \& Willard ST. (2004). Applied animal reproduction. $6^{\text {th }}$ ed. New Jersey: Pearson Prenctice Hall.

Feradis. (2010). Bioteknologi reproduksi pada ternak. Bandung: Alfabeta.

Fulton, J.E. (2006). Avian genetic stock preservation: An industry perspective. Poult Sci, 85, 227-231.

Garner, D.L.E., \& Hafez, S.E. (2000). Spermatozoa and seminal plasma. In: Reproduction in farm animals. 7th Ed B Hafez/ESE Hafez USA: Lippincott Williams \& Wilkins.

Khaeruddin. (2020). Pembekuan spermatozoa ayam kampung dengan suplementasi bovine serum albumin dan putih telur dalam pengencer ringer laktat kuning telur. Ternak Tropika, 21(2), 111-222.

Khaeruddin, Junaedi, \& Hastuti. (2020). Cryopreservation of Indonesian native chicken semen by using dimethyl sulfoxide and various level of ethylene glycol as cryoprotectants. Biodiversitas, 21 (12), 5718-5722.

Khaeruddin, \& Kurniawan, M.E. (2020). Keberhasilan pembekuan semen ayam yang diencerkan dengan glukosa, trehalosa, sukrosa dan laktosa. Jurnal Veteriner, 21(3), 476-484.

Khairuddin, Kurniawan, M.E., \& Soman. (2019). Cryopreservation of Kampung rooster semen using egg yolk diluent from four types of poultry with different concentrations. Jurnal Kedokteran Hewan, 13(3), 60-65.

Malik, A. (2018). Penambahan madu pada pengencer skim milk-egg yolk terhadap motilitas spermatozoa pasca thawing pada ayam kampung. 
Prosiding seminar nasional kebangkitan peternakan III. 38-42.

Partodihardjo. (1992). Ilmu reproduksi hewan. Jakarta: Mutiara Sumber Widya.

Pratiwi, R.I., Suharyatib, S., \& Hartono, M. (2014). Analisis kualitas semen beku sapi simmental menggunakan pengencer andromed dengan variasi waktu prefreezing. Jurnal Ilmiah Peternakan Terpadu, 2(3), 8-15.
Purwasih, R., Ondho, S.Y., \& Sutopo. (2013). Efektivitas prefreezing semen sapi jawa sebagai parameter keberhasilan processing semen beku. Animal Agriculture Journa, 2(1), 44-50.

Salamon, S. (1971). Fertility of ram spermatozoa following pellet freezing on dry ice at $-79{ }^{\circ} \mathrm{C}$ and $140{ }^{0}$ C. Aust. J. Biol.Sci, 24, 183185. 